\title{
PEMANFAATAN KARBON SEBAGAI FILTER UNTUK PENGENDALIAN PENCEMARAN AIR SUNGAI OLEH LOGAM Zn (seng) DARI LIMBAH PABRIK KELAPA SAWIT DI KABUPATEN KUANSING
}

\author{
Riad Syech $^{1}$, Restina $^{2,}{ }^{,}$, Usman Malik $^{1}$ \\ ${ }^{1}$ Dosen Jurusan Fisika \\ ${ }^{2}$ Mahasiswa Program Studi S1 Fisika \\ Fakultas Matematika dan Ilmu Pengetahuan Alam, \\ Universitas Riau Kampus Bina Widya \\ J1. Prof. Muchtar Luthfi Pekanbaru, 28293, Indonesia \\ *E-mail: Restinaphysic@gmail.com
}

\begin{abstract}
A research has been conducated on using charcoal as a filter to control river water pollution with heavy metals from palm oil mill waste based on physical parameters in Kuantan Singingi district using SSA method. The process begin with taking sample from palm iol mill waste output, the the temperature and electrical conductivity of it is mesured. Heavy metal concentration (Zn) is mesured with Atomic Absorption (SSA). The highest electrical conductivity value before filtrasion was found in factory A sampel. The value is $8,87 \times 10^{-4}$ $m^{-1}$ with $0,241 \mathrm{mg} / \mathrm{Z} \mathrm{Zn}$ concetration. Electrical conductivity value decreased after filtration to $7,11 \times 10^{-4} \mathrm{~m}^{-1}$ with $0,216 \mathrm{mg} / \mathrm{l} \mathrm{mg/l} \mathrm{Zn} \mathrm{concetration.} \mathrm{While} \mathrm{the} \mathrm{lowest} \mathrm{electrical} \mathrm{conductivity} \mathrm{value} \mathrm{before} \mathrm{filtration} \mathrm{was} \mathrm{found}$ in factory C sample. The value is 4,65 $\times 10^{-4} \mathrm{~m}^{-1}$ with $0,169 \mathrm{mg} / \mathrm{Zn}$ consetration. Conductivity value decreased after filtration to 4,26 $\times 10^{-4} \mathrm{~m}^{-1}$ with $0,154 \mathrm{mg} / \mathrm{Zn}$ contretation. These result explain that using charcoal as a filter for pollution control is uqite effective.
\end{abstract}

Keyword : Charcoal, pollution, oil palm factory, physical parameter.

\begin{abstract}
ABSTRAK
Telah dilakukan penelitian tentang pemanfaatan arang sebagai filter untuk pengendalian pencemaran air sungai oleh logam berat dari limbah pabrik kelapa sawit berdasar parameter fisis di kabupaten kuantan singingi menggunakan SSA. Proses dimulai dengan mengambil sampel keluaran limbah pabrik kelapa sawit, kemudian diukur suhu dan konduktivitas listrik air limbah. Pengukuran konsentrasi logam berat (Zn) dilakukan dengan Spektrometer Serapan Atom (SSA). Hasil yang diperoleh menunjukkan bahwa nilai konduktivitas listrik sebelum penyaringan menggunakan arang paling tinggi yaitu pada sampel pabrik A yaitu sebesar $8,87 \times 10^{-4}$ $m^{-1}$ dengan konsentrasi $\mathrm{Zn} 0,241 \mathrm{mg} / \mathrm{l}$. Setelah dilakukan penyaringan menjadi 7,11 $\times 10^{-4} \mathrm{~m}^{-1}$ dengan konsentrasi logam berat Zn 0,216 mg/l sedangkan konduktivitas listrik paling rendah yaitu pada sampel pabrik C sebelum penyaringan sebesar 4,65 × $10^{-4} \mathrm{~m}^{-1}$ dengan konsentrasi logam berat Zn sebesar 0,169 mg/l dan setelah dilakukan penyaringan menjadi 4,26 $\times 10^{-4} \mathrm{~m}^{-1}$ dengan konsentrasi logam berat Zn sebesar 0,154 mg/l. Hasil ini menjelaskan pemanfaatan arang sebagai filter untuk pengendalian pencemaran cukup efektif.
\end{abstract}

Kata kunci : Arang, pencemaran, pabrik kelapa sawit, parameter fisis.

\section{PENDAHULUAN}

Limbah pada dasarnya adalah bahan yang terbuang atau dibuang dari suatu sumber hasil aktivitas manusia, maupun proses-proses alam yang mempunyai nilai ekonomi negatif. Limbah industri pabrik kelapa sawit adalah berupa limbah padat, gas dan cair. Limbah cair adalah limbah yang mempunyai sifat cair dimana komposisinya meliputi bahan organik dan anorganik dan lainnya dan bahan pencemar yang besar sehingga apabila di alirkan ke sungai tanpa memenuhi baku mutu yang telah ditetapkan pemerintah akan menyebabkan pencemaran sungai.

Sungai adalah salah satu sumber daya alam yang sering digunakan masyarakat untuk kegiatan sehari-hari. Peran sungai disetiap tempat sangat penting untuk 
keseharian masyarakat. Beberapa sungai tidak memenuhi baku mutu yang layak digunakan masyarakat, karena masih banyak pencemaran sungai terjadi akibat ulah manusia. Sebab itu dibutuhkan uji kualitas air limbah keluaran pabrik saawit dan cara pengendaliannya menggunakan arang tempurung kelapa sebagai filter dengan mengukur parameter Fisika yaitu Suhu, konduktivitas listrik serta kandungan logam berat air sungai.

\section{TINJAUAN PUSTAKA}

\section{Pencemaran air sungai}

Air adalah sumber kehidupan di muka bumi ini, kita semua bergantung pada air sehingga diperlukan air yang dapat dipergunakan sebagaimana mestinya. Pencemaran air sungai terjadi apabila dalam air sungai tedapat berbagai macam zat atau kondisi yang dapat menurunkan standar kualitas air yang telah ditentukan, sehingga tidak dapat digunakan untuk kebutuhan tertentu. Sumber air dikatakan tercemar tidak hanya karena tercampur dengan bahan pencemar, akan tetapi apabila air tersebut tidak sesuai dengan kebutuhan tertentu, contoh suatu sungai yang tercemar logam berat atau bakteri penyakit sehingga tidak dapat digunakan untuk kebutuhan rumah tangga.

\section{Limbah cair industri sawit}

Limbah cair industri kelapa sawit berasal dari unit proses pengukusan (sterilisasi), proses klarifikasi dan buangan dari hidrosiklon. Limbah cair industri minyak kelapa sawit mengandung bahan organik yang sangat tinggi, sehinggga kadar bahan pencemar akan semakin tinggi [1]. Dampak yang ditimbulkan oleh limbah cair industri sawit adalah tercemarnya badan air penerima yang umumnya sungai karena hampir setiap industri minyak kelapa sawit berlokasi didekat sungai. Salah satu teknik pengendalian pencemaran air limbah adalah dengan melakukan penyaringan menggunakan arang sebagai penyerap kompenen organik.

\section{Parameter fisika mempengaruhi air sungai}

Suhu dari suatu badan air dipengaruhi oleh musim, lintang (latitute), ketinggian dari permukaan laut, waktu dalam hari sirkulasi udara, penutupan awan, dan aliran serta kedalaman badan air adalah salah satu faktor yang sangat penting bagi kehidupan organisme, karena suhu mempengaruhi baik aktivitas metabolisme maupun pengembang biakan organisme-organisme tersebut [2]. Kisaran suhu yang baik untuk menunjang pertumbuhan optimal adalah $28-32^{\circ} \mathrm{C}$.

Daya hantar listrik adalah bilangan yang menyatakan kemampuan larutan cair untuk menghantarkan arus listrik. Konduktivitas atau daya hantar merupakan ukuran kemampuan mengalirkan arus listrik, menandakan banyaknya ion yang terkandung didalamnya [2]. Resistivitas ( $\rho$ ) adalah kemampuan suatu bahan untuk mengantarkan arus listrik yang bergantung terhadap besarnya medan istrik dan kerapatan arus. Semakin besar resistivitas suatu bahan maka semakin besar pula medan listrik yang dibutuhkan untuk menimbulkan sebuah kerapatan arus. Satuan untuk resistivitas adalah .m. Secara matematis dirumuskan seperti berikut :

$$
K=\frac{\rho}{A}
$$

\section{Logam berat Seng (Zn)}

Seng (Zn) adalah logam yang putih kebiruan, logam ini sangat mudah ditempa dan liat pada suhu $110-150{ }^{\circ} \mathrm{C}$. Zink melebur pada $410{ }^{\circ} \mathrm{C}$ dan mendidih pada $906^{\circ} \mathrm{C}$. Seng $(\mathrm{Zn})$ dalam pemanasan tinggi akan menimbulkan endapan seperti pasir. Seng (Zn) diperlukan tubuh untuk proses 
metabolisme, tetapi dalam kadar tinggi dapat bersifat menjadi racun [3].

Seng dialam tidak berada dalam keadaan bebas, tetapi dalam bentuk terikat dengan unsur lain berupa mineral. Seng juga merupakan salah satu bentuk materi anorganik yang sering menimbulkan berbagai permasalahan yang cukup serius pada perairan. Konsentrasi logam berat pada air akan mempengaruhi konsentrasi logam berat yang ada pada sedimen. Kecendrungan peningkatan konsentrasi logam berat di sedimen diakibatkan oleh tingginya konsentrasi logam berat tersebut di air. Selain itu, terdapat parameter-parameter lain yang berpengaruh dalam kesetimbangan reaksi di sistem perairan, seperti suhu, konsentrasi logam dan tipe senyawanya, kondisi reduksi-oksidasi perairan, dan bilangan oksidasi dari logam tersebut.

\section{Spektroskopi Serapan Atom (SSA)}

Spektrofotometer serapan atom (SSA) adalah suatu alat yang digunakan untuk melihat unsur-unsur logam dengan panjang gelombang tertentu melalui penyerapan cahaya oleh atom-atom tertentu dalam keadaan bebas. Atom-atom mengabsorbsi cahaya tersebut pada panjang gelombang tertentu, tergantung pada sifat unsurnya. Ketika terjadi radiasi, elektron berada pada transisi dari keadaan energi satu ke energi yang lainnya. Saat tereksitasi (tingkat energi tinggi) dan kembali lagi pada keadaan dasar (energi terendah) dengan melepas energi foton pada energi yang sama. Atom dapat menyerap jika energi pada keadaan tinggi dasar melalui foton [4].

Hubungan antara konsentrasi dengan absorbansi didapat dari:

1. Hukum Lambert: bila suatu sumber sinar monokromatik melewati medium transparan, maka intensitas sinar yang diteruskan berkurang dengan bertambahnya ketebalan medium yang mengabsorbsi.
2. Hukum Beer: intensitas sinar yang diteruskan berkurang secara eksponensial dengan bertambahnya konsentrasi spesi yang menyerap sinar tersebut [5].

Berdasar hukum Beer diperoleh persamaan:

$$
\mathrm{A}=\mathrm{E} \times \mathrm{b} \times \mathrm{c}
$$

\section{Karbon}

Karbon merupakan suatu padatan berpori yang mengandung 85,95\% unsur karbon yang dihasilkan dari bahan-bahan yang mengandung karbon dengan pemanasan pada suhu tinggi. Karbon selain digunakan sebagai bahan bakar, juga dapat digunakan sebagai adsorben (penyerap). Daya serap ditentukan oleh luas permukaan partikel dan kemampuan ini dapat menjadi lebih tinggi jika terhadap karbon tersebut dilakukan aktivasi dengan aktivator bahan- bahan kimia ataupun dengan pemanasan pada temperatur tinggi. Karbon akan mengalami perubahan sifat fisika dan sifat kimia. Karbon menyerap kandungan-kandungan tertentu didalam suatu zat cair.

\section{Arang tempurung kelapa}

Arang merupakan adsorben yang sangat efisien karena butiran padatan yang sangat halus. Arang tempurung kelapa mempunyai daya untuk mengadsorpsi ion logam $\mathrm{Zn}$. Arang tempurung kelapa adalah arang yang menghasilkan karbon dengan poro-pori lebih terbuka. Arang tempurung kelapa mempunyai permukaan yang luas dan berongga dengan sruktur yang berlapis.Ini menyebabkan arang tempurung kelapa dapat menyerap gas atau zat lain dalam larutan dan udara.

\section{Filtrasi (penyaringan)}

Filtrasi adalah proses pemisahan dari campuran heterogen yang mengandung cairan dan partikel-partikel padat dengan 
menggunakan media filter hanya meloloskan cairan dan menahan partikel-partikel padat. Proses pemisahan dengan cara filtrasi dapat dibedakan berdasarkan adanya tekanan dan tanpa tekanan. Proses filtrasi sederhana (tanpa tekanan) adalah proses penyaringan dengan media filter kertas saring. Penyaringan dilakukan dengan cara kertas saring dipotong melingkar, kemudian lipat dua sebanyak tiga atau empat kali. Selanjutnya buka dan letakkan dalam corong pisah sehingga melekat pada corong pisah. Tuangkan campuran heterogen yang akan dipisahkan sedikit demi sedikit. Hasil filtrasi adalah zat padat yang disebut residen dan zat cairnya disebut dengan fitrat.

\section{METODE PENELITIAN}

\section{Pengambilan sampel}

Sampel diambil pada tiga pabrik kelapa sawit yang berada dikabupaten Kuansing. Pabrik sawit PT Usaha Kita Makmur diberi label A, PT Tamora Agro Lestari diberi label B dan PT Mustika Agro Sari diberi label C. Sampel diambil pada kolam limbah terakhir atau limbah keluaran sebelum dibuang kesungai. Sampel diambil pada jam \pm 09.00 wib dipinggir kolam sekitar pipa penyaringan limbah sebelumnya, sampel diambil menggunakan botol air mineral dengan kedalaman rata-rata $10 \mathrm{~cm}$.

\section{Skema penelitian}

Penyaringan air limbah pabrik kelapa sawit seperti pada Gambar 1. filter arang digunakan untuk mengurangi kadar pengotor atau logam berat pada limbah pabrik kelapa sawit sehingga badan air penerima air limbah tidak tercemar bahan organik dan anorganik limbah. Arang tempurung kelapa yang digunakan adalah arang yang dijual dipasaran. Arang tempurung kelapa yang akan digunakan dipotong kecil dengan ukuran rata-rata $2 \mathrm{~cm}$ dan dtimbang masingmasing 10 gram kemudian direndam selama
2 menit menggunakan aquades sebagai kalibrasi. Tahap awal dari pengukuran adalah melakukan pengukuran tanpa ada penyaringan, selanjutnya penyaringan menggunakan kertas saring dan arang volume sampel yang digunakan untuk masing-masing pengukuran adalah $200 \mathrm{~mL}$. Proses ini diulangi untuk masing -masing pengujian logam berat dan parameter fisika.

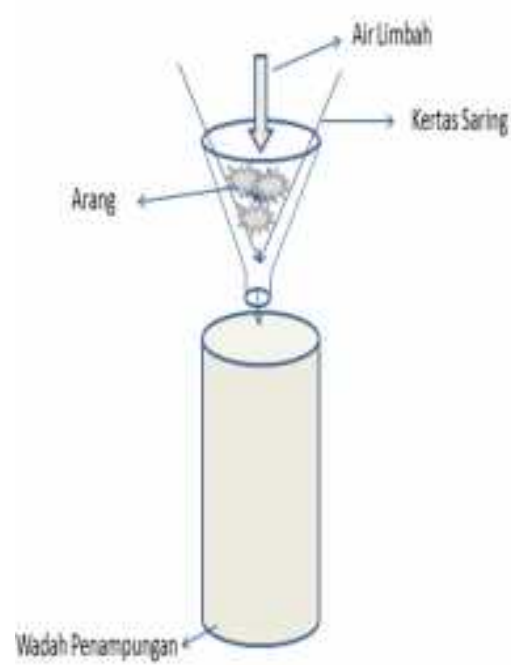

Gambar 1. Skema Penyaringan Sampel.

\section{Analisis parameter fisika}

Pengukuran suhu dilakukan dengan cara memasukkan termometer pada sampel yang telah diberi label, suhunya diamati dan catat kedalam tabel data.

Pengukuran konduktivitas listrik dilakukan dengan memasukan sel platina yang terdapat pada konduktiviti meter kedalam gelas beker yang sudah berisi 40 $\mathrm{mL}$ sampel air, kemudian nyalakan konduktiviti meter dan catat hasil pengukuran yang ditunjukkan pada konduktivitimeter. Setelah konduktiviter meter digunakan bersihkan dengan aquades.

\section{Mengukur konsentrasi logam berat air sungai batang lubuh menggunakan Spektrofometer Serapan Atom (SSA)}

Pengukuran konsentrasi logam berat $\mathrm{Cu}$, $\mathrm{Zn}$ dan $\mathrm{Pb}$ yang terdapat dalam sampel 
menggunakan spektroskopi serapan atom. Pengukuran dilakukan dengan cara Alirkan Asetilen ke Spektrofometer dengan membuka aliran dari tabung gas. Atur lampu katoda berongga untuk $\mathrm{Cu}, \mathrm{Zn}$ dan $\mathrm{Pb}$. Inputkan parameter sampel yang akan dianalisa ke komputer, secara otomatis alat akan menyesuaikan datanya. Jalankan alat dan masukkan pipa penghisap spektrofometer kedalam tabung reaksi larutan standar $\mathrm{Cu}$ dan sampel air sungai secara berurutan sesuai penomoran nya.Ulangi langkah 4 untuk logam $\mathrm{Zn}$ dan $\mathrm{Pb}$ lalu cetak data.

\section{HASIL DAN PEMBAHASAN}

Hasil pengukuran suhu sampel, konduktivitas listrik dan konsentrasi logam berat $\mathrm{Zn}$ dapat dilihat pada tabel dibawah.

Analisa nilai pengukuran konduktivitas listrik dan suhu sampel air limbah pabrik kelapa sawit sebelum dan sesudah penyaringan

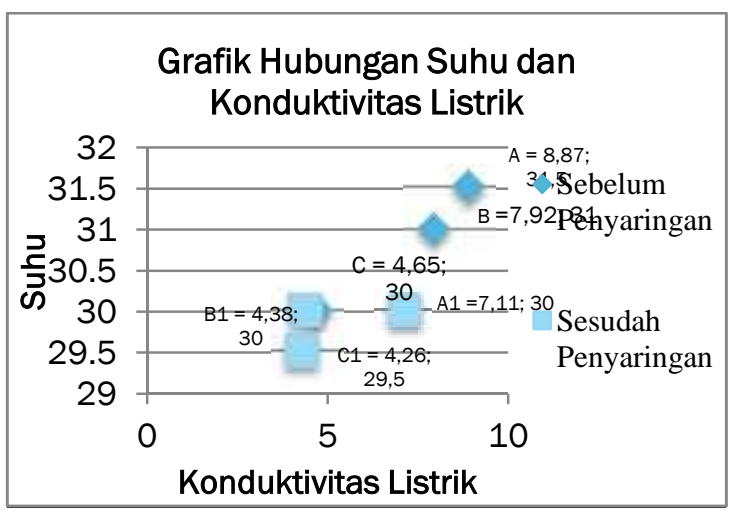

Gambar 2 Grafik hubungan suhu dan konduktivitas limbah keluaran sawit sebelum dan sesudah penyaringan menggunakan arang.

Gambar 2 menunjukkan grafik hubungan antara nilai konduktivitas listrik dan suhu air limbah pabrik kelapa sawit sebelum dan sesudah penyaringan menggunakan arang sebagai filter pada tiga pabrik kelapa sawit. Suhu mempengaruhi besarnya konduktivitas listrik. Semakin tinggi nilai suhu air limbah maka semakin besar nilai konduktivitas listriknya. Ini disebabkan kenaikan suhu akan meningkatkan pergerakan ion-ion dalam larutan sehingga konduktivitas larutan meningkat.

Tabel 1. Hasil Pengukuran Suhu, Konduktivitas Listrik, Konsentrasi Logam Berat Seng dan Absorbansi Sampel.

\begin{tabular}{|c|c|c|c|c|}
\hline Samp & $\begin{array}{l}\text { Suhu } \\
\left({ }^{\circ} \mathrm{C}\right)\end{array}$ & 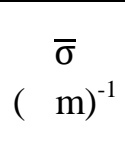 & $\begin{array}{c}\text { Ko. Zn } \\
\mathrm{mg} / \mathrm{l}\end{array}$ & $\begin{array}{c}\text { Absorb } \\
\times 10^{-10} \\
\left(\mathrm{Kg}^{2} / \mathrm{s}\right)\end{array}$ \\
\hline S. A & 31,5 & $\begin{array}{c}8,87 \mathrm{x} \\
10^{-4}\end{array}$ & 0,241 & 2,5775 \\
\hline S. A1 & 30 & $\begin{array}{c}7,11 \times \\
10^{-4}\end{array}$ & 0,216 & $\begin{array}{c}2,3101 \\
2\end{array}$ \\
\hline S. B & 31 & $\begin{array}{c}7,92 \times \\
10^{-4}\end{array}$ & 0,235 & $\begin{array}{c}2,5133 \\
25\end{array}$ \\
\hline S. B1 & 30 & $\begin{array}{c}4,38 \times \\
10^{-4}\end{array}$ & 0,214 & $\begin{array}{c}2,2887 \\
3\end{array}$ \\
\hline S.C & 30 & $\begin{array}{c}4,65 \mathrm{x} \\
10^{-4}\end{array}$ & 0,169 & $\begin{array}{c}1,8074 \\
55\end{array}$ \\
\hline S. C1 & 29,5 & $\begin{array}{c}4,26 \mathrm{x} \\
10^{-4}\end{array}$ & 0,154 & $\begin{array}{c}1,6470 \\
3\end{array}$ \\
\hline
\end{tabular}

Nilai pengukuran konduktivitas listrik di tiga pabrik sebelum dan sesudah penyaringan menggunakan arang. Nilai konduktivitas paling kecil yaitu pada pabrik $\mathrm{C}$ sebesar 4,65 x $10^{-4}(\mathrm{~m})^{-1}$ dengan suhu $30^{\circ} \mathrm{C}$ Rendahnya nilai konduktivitas listrik menunjukkan air limbah memiliki kandungan mineral organik dan anorganik yang sedikit sehingga mineralmineral yang dapat menghantarkan arus listrik untuk mengalir lebih kecil.

Konduktivitas listrik paling tinggi terdapat pada pengukuran sampel pabrik A sebesar $8,87 \times 10^{-4}(\mathrm{~m})^{-1}$ dengan suhu $31,5{ }^{\circ} \mathrm{C}$. Tingginya nilai konduktivitas mengakibatkan nilai resistivitas semakin kecil ini menunjukkan kemampuan untuk menghambat arus listrik yang mengalir juga kecil, sedangkan mineral-mineral yang bisa menghantarkan arus listrik yang terkandung sangat besar sehingga daya hantar listriknya akan semakin besar. Semakin besar nilai konduktivitas listrik maka menunjukkan semakin buruk kualitas air limbah karna 
memiliki kandungan mineral organik dan anorganik pencemar yang banyak.

Setelah dilakukan penyaringan menggunakan arang sebagai filter maka didapat nilai pengukuran sebelum dan sesudah penyaringan dengan urutan dari konduktivitas tinggi sampai terendah yaitu pabrik A sebelum penyaringan sebesar $8,87 \times 10^{-4}(\mathrm{~m})^{-1}$ menjadi $7,11 \times 10^{-4}(\mathrm{~m})^{-1}$ setelah penyaringan, pabrik B sebesar 7,92 x $10^{-4}(\mathrm{~m})^{-1}$ menjadi 4,38 x 10${ }^{4}(\mathrm{~m})^{-1}$ dan pabrik $\mathrm{C}$ sebesar $4,65 \times 10^{-4}(\mathrm{~m})^{-}$ ${ }^{1}$ menjadi 4,26 x $10^{-4}(\mathrm{~m})^{-1}$. Arang mampu menjadi filter yang cukup baik dalam menyerap kandungan mineral dalam sampel. Arang bisa menjadi penyerap yang baik karna arang mengalami perubahan sifat kimia dan fisika pada saat pemanasan sehingga arang dapat menyerap kandungan-kandungan tertentu dalam suatu zat cair. Arang dapat menyerap ribuan kali beratnya sendiri seperti zat-zat berupa gas, logam, berat dan racunracun dan bahan kimia lainnya.

Analisa nilai pengukuran suhu dan konsentrasi logam $\mathrm{Zn}$ air limbah keluaran pabrik kelapa sawit A, B dan $\mathrm{C}$ sebelum dan sesudah penyaringan

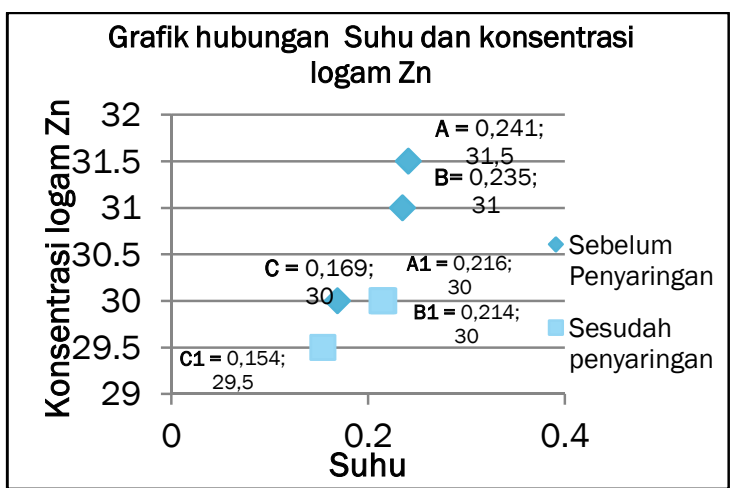

Gambar 3 Grafik hubungan konsentrasi logam $\mathrm{Zn}$ dan Suhu sebelum dan sesudah penyaringan menggunakan arang.

Gambar 3 menunjukkan hubungan antara konsentrasi logam $\mathrm{Zn}$ dan suhu air limbah sebelum dan sesudah penyaringan menggunakan arang sebagai filter pada tiga pabrik kelapa sawit. Semakin tinggi suhu air limbah maka tinggi pula konsentrasi logam $\mathrm{Zn}$ begitu juga sebaliknya pada saat terjadi penurunan suhu maka konsentrasi logam $\mathrm{Zn}$ juga menurun.

Konsentrasi logam berat seng ( $\mathrm{Zn}$ ) paling tinggi terlihat pada pabrik A yaitu sebesar 0,241 mg/l, sedangkan konsentrasi logam berat seng $(\mathrm{Zn})$ terendah terletak pada sampel pabrik C. Hasil pengukuran yang didapat sebelum dan sesudah penyaringan menggunakan arang yaitu pabrik A sebelum penyaringan sebesar $0,241 \mathrm{mg} / \mathrm{l}$ menjadi $0,216 \mathrm{mg} / \mathrm{l}$, pabrik $\mathrm{B}$ sebesar $0,235 \mathrm{mg} / \mathrm{l}$ menjadi $0,214 \mathrm{mg} / \mathrm{l}$ dan pabrik C sebesar $0,169 \mathrm{mg} / \mathrm{l}$ menjadi 0,154 $\mathrm{mg} / \mathrm{l}$. Hal ini menunjukkan arang cukup efektif sebagai filter dalam menyerap kandungan logam atau mineral dalam suatu zat cair, sehingga tumbukan yang terjadi antar partikel akan berkurang dan terjadi penurunan suhu.

\section{Analisa hubungan konsentrasi logam seng (Zn) dan absorbansi air limbah pabrik kelapa sawit sebelum dan sesudah penyaringan}

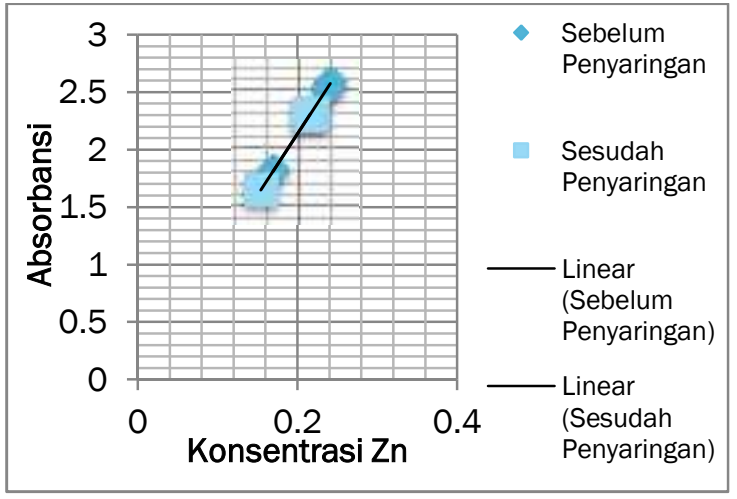

Gambar 4. Grafik hubungan konsentrasi logam seng (Zn) dan absorbansi sebelum dan sesudah penyaringan.

Gambar 4 menunjukkan hubungan antara konsentrasi logam Zn dan absorbansi secara perhitungan sebelum dan sesudah penyaringan menggunakan arang. Berdasar hukum Beer intensitas sinar yang diteruskan berkurang secara eksponensial dengan bertambahnya konsentrasi spesi yang menyerap sinar tersebut sehingga dapat dapat dilihat absorbansi berbanding lurus dengan konsentrasi logam $\mathrm{Zn}$ (seng) dan sesuai dengan teoritis. Gambar 4 
menunjukkan hubungan antara konsentrasi logam $\mathrm{Zn}$ dan absorbansi secara perhitungan sebelum dan sesudah penyaringan menggunakan arang. Berdasar hukum Beer intensitas sinar yang diteruskan berkurang secara eksponensial dengan bertambahnya konsentrasi spesi yang menyerap sinar tersebut sehingga dapat dapat dilihat absorbansi berbanding lurus dengan konsentrasi logam $\mathrm{Zn}$ (seng) dan sesuai dengan teoritis.

Analisa hubungan konduktivitas listrik dan konsentrasi logam Zn air limbah sebelum dan sesudah penyaringan

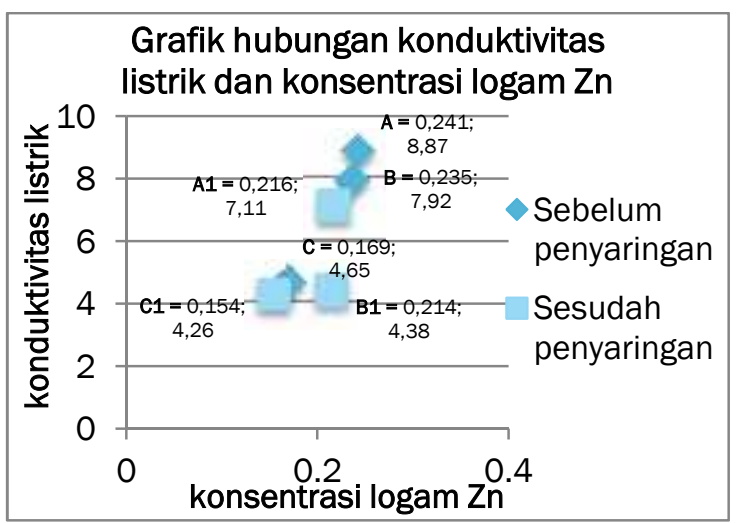

Gambar 5. Grafik hubungan konduktivitas listrik dan konsentrasi logam seng (Zn) air limbah pabrik kelapa sawit.

Gambar 5 menunjukkan hubungan antara konduktivitas dan konsentrasi logam Zn sebelum dan sesudah penyaringan. Semakin tinggi konsentrasi dari logam berat $\mathrm{Zn}$ maka nilai konduktivitasnya juga semakin meningkat. Pada pabrik A konsentrasi logam $\mathrm{Zn} 0,241 \mathrm{mg} / \mathrm{l}$ dengan konduktivitas $8,87 \times 10^{-}$ ${ }^{4}(\mathrm{~m})^{-1}$, pabrik B $0,235 \mathrm{mg} / \mathrm{l}$ konduktivitas $7,92 \times 10^{-4}(\mathrm{~m})^{-1}$ dan pabrik $\mathrm{C}$ konsentrasi $0,165 \mathrm{mg} / \mathrm{l}$ dengan konduktivitas 4,65 $10^{-4}$ $(\mathrm{m})^{-1}$. Tingginya nilai konduktivitas pada pabrik A menunjukkan Kualitas air limbah cukup buruk dimana limbah mengandung mineral organik dan anorganik pencemar yang banyak, Setelah dilakukan penyaringan konsentrasi logam $\mathrm{Zn}$ dan konduktivitas mengalami penurunan hal ini dikarenakan mineral-mineral pengotor diserap oleh arang pada saat terjadi filtrasi sehingga mineral yang menghantarkan listrik semakin sedikit begitu juga dengan konsentrasi logam $\mathrm{Zn}$.

Analisa konsentrasi logam berat $\mathrm{Zn}$ air limbah pabrik kelapa sawit sebelum dan sesudah penyaringan menggunakan arang

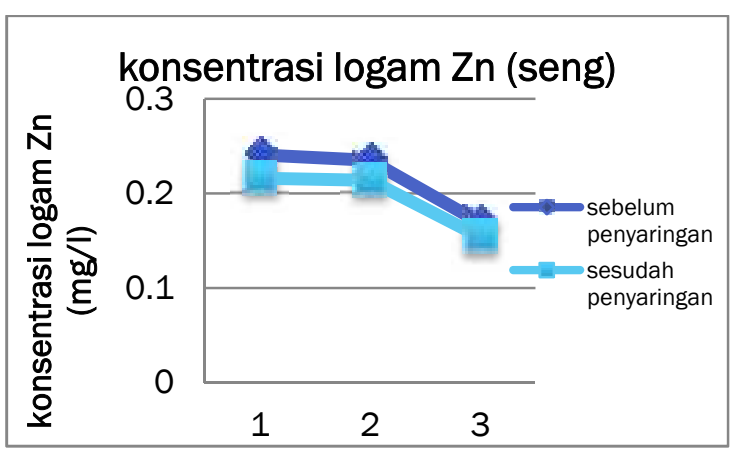

Gambar 6. Grafik konsentrasi logam $\mathrm{Zn}$ air limbah pabrik kelapa sawit sebelum dan sesudah penyaringan menggunakan arang.

Gambar 6 menunjukkan konsentrasi logam $\mathrm{Zn}$ air limbah ditiga pabrik kelapa sawit sebelum dan sesudah penyaringan menggunakan arang. Konsentrasi logam berat seng (Zn) paling tinggi terlihat pada pabrik A yaitu sebesar $0,241 \mathrm{mg} / \mathrm{l}$ hal ini dikarenakan pengolahan limbah cair pabrik kelapa sawit pada pabrik belum sempurna dan memiliki jumlah kolam paling sedikit dibanding pabrik lainnya, sedangkan konsentrasi logam berat seng $(\mathrm{Zn})$ terendah terletak pada sampel pabrik $\mathrm{C}$ dimana pengolahan limbah pabrik $\mathrm{C}$ memiliki 16 kolam penyaringan. Hasil pengukuran yang didapat sebelum dan sesudah penyaringan menggunakan arang yaitu pabrik A sebelum penyaringan sebesar $0,241 \mathrm{mg} / \mathrm{l}$ menjadi $0,216 \mathrm{mg} / \mathrm{l}$, pabrik $\mathrm{B}$ sebesar 0,235 $\mathrm{mg} / \mathrm{l}$ menjadi $0,214 \mathrm{mg} / \mathrm{l}$ dan pabrik $\mathrm{C}$ sebesar $0,169 \mathrm{mg} / \mathrm{l}$ menjadi $0,154 \mathrm{mg} / \mathrm{l}$. Konsentrasi logam $\mathrm{Zn}$ pada tiga pabrik mengalami penurunan. Hasil perhitungan efisiensi penyerapan arang pada sampel air limbah keluaran pabrik kelapa sawit berturut-turut adalah $10,37 \%, 8,93 \%, 8,876 \%$. Sehingga dapat disimpulkan arang cukup efektif dapat digunakan sebagai filtrasi pada limbah keluaran pabrik kelapa sawit sebelum dibuang ke sungai. 


\section{KESIMPULAN}

Arang dapat digunakan sebagai pengendalian pencemaran air sungai oleh logam berat dari limbah pabrik kelapa sawit. Konduktivitas listrik rata-rata paling tinggi pada sampel air limbah keluaran terdapat pada pabrik A yaitu sebesar $8,87 \times 10^{-4}(\mathrm{~m})^{-1} \quad$ sedangkan konduktivitas paling rendah terdapat pada sampel pabrik C sebesar 4,65 $\times 10^{-4}(\mathrm{~m})^{-1}$. Setelah dilakukan penyaringan menggunakan arang tempurung kelapa konduktivitas listrik turun menjadi $7,11 \times 10^{-4}(\mathrm{~m})^{-1}$ dan 4,26 x $10^{-4}(\mathrm{~m})^{-1}$ Semakin besar nilai konduktivitas air maka kandungan logam beratnya juga semakin tinggi, sedangkan semakin kecil nilai konduktivitas air maka kandungan logam berat juga semakin rendah. Konsentrasi logam berat Seng (Zn) pada ketiga limbah keluaran pabrik kelapa sawit di Kuantan Singingi berada diatas batas maksimum konsentrasi yang diperbolehkan (Zn 0,05 mg/l) maka air limbah keluaran pabrik kelapa sawit berkualitas buruk dan dapat mencemari sungai, setelah dilakukan penyaringan menggunakan arang konsentrasi mengalami penurunan. Efisiensi penyerapan arang tempurung kelapa pada sampel air limbah berturut-turut adalah $10,37 \%, 8,93 \%$ dan $8,876 \%$.

\section{DAFTAR PUSTAKA}

1. Azwir. (2006). Analisa Pencemaran Air Sungai Tapung Kiri oleh Limbah Industri Kelapa Sawit PT. Peputra Masterindo di Kabupaten Kampar. Tesis Universitas Diponegoro, Semarang.

2. Abdi, R. (2016). Penentuan Kounduktivitas listrik Sungai Batang Lubuh Menggunakan Metode Jembatan Wheatstone. Skripsi Jurusan Fisika FMIPA, Universitas Riau, Pekanbaru

3. Herniwati. (2012). Uji Kelayakan Limbah Cair Pabrik Kelapa Sawit PT. Perkebunan Nusantara II Prafi-Manokwari. Skripsi Universitas Negri Papua. Manokwari.

4. Putri, R. A. (2013). Pembuatan Karbon Aktif Dari Ampas Tebu Untuk Penyerapan Logam Berat (Zn dan Fe) di Sungai Siak. Skripsi Jurusan Fisika FMIPA, Universitas Riau, Pekanbaru

5. Salam, A. H. (2013). Menentukan Pola Penyebaran Logam Berat ( $\mathrm{Cu}, \mathrm{Fe}, \mathrm{Zn}$ ) di Sungai Siak dengan Menggunakan Spektrofotometer ( SAA ). Skripsi Jurusan Fisika FMIPA, Universitas Riau, Pekanbaru. 